\title{
EVALUASI KAMPUNG KOTA BERKELANJUTAN MELALUI PENDEKATAN ASIAN NEW URBANISM (STUDI KASUS: KAMPUNG JAMBANGAN KOTA SURABAYA)
}

\author{
Siti Nuurlaily Rukmana ${ }^{1}$ \\ Sucipto ${ }^{2}$ \\ Program Studi Perencanaan Wilayah dan Kota, Universitas PGRI Adi Buana Surabaya ${ }^{1}$ \\ Program Studi Manajemen Wisata, Universitas Terbuka Surabaya ${ }^{2}$ \\ Penulis Korespondensi e-mail : nuurlaily_rukmana@unipasby.ac.id
}

\begin{abstract}
The success of Jambangan village (kampung) as one of the best environmental management icons in Surabaya and has won an award as the Best of the Best Category in 2011 has become one of the villages (kampung) that has been named a sustainable village. There are four concepts of Jambangan village including the village of learning, healthy village, foster village, creative village, and safe village. Asian new urbanism approach is one of the approaches used to measure the sustainability of a region where this approach is suitable for the behavior or customs of life in Asia. The objective of this study was to evaluate to what extent sustainable villages at Jambangan have been implemented based on the Asian new urbanism approach. This study is descriptive qualitative research. This study used a triangulation technique to maintain its validity. The evaluation results of Jambangan sustainable village are consistent with the Asian new urbanism approach by $80 \%$. The sustainability of Jambangan village is influenced by the community's sense of belonging to the environment and it begins from strengthening the potential of the village so that the people prosper.
\end{abstract}

Keywords: Asian New Urbanism, Sustainable, Urban Village

\begin{abstract}
ABSTRAK
Keberhasilan kampung Jambangan sebagai salah satu icon pengelolaan lingkungan terbaik di Kota Surabaya serta pernah meraih penghargaan sebagai Best of the Best Category di Tahun 2011 menjadi salah satu kampung yang dinobatkan sebagai kampung berkelanjutan. Terdapat empat konsep yang dimiliki oleh Kampung Jambangan yaitu kampung belajar, kampung sehat, kampung asuh, kampung kreatif dan kampung aman. Pendekatan Asian new urbanism merupakan salah satu pendekatan yang digunakan untuk mengukur keberlanjutan suatu kawasan dimana pendekatan ini sesuai dengan prilaku/kebiasaan hidup di Asia. Tujuan penelitian ini yaitu untuk mengevaluasi sejauh mana kampung berkelanjutan di jambangan telah diterapkan sesuai dengan pendekatan Asian new urbanism. Metode yang digunakan adalah deskriptif kualitatif. Guna menjaga keabsahan penelitian ini maka dilakukan teknik triangulasi peneliti. Hasil evaluasi kampung berkelanjutan Jambangan yang sesuai dengan pendekatan asian new urbanism sebesar 80\%. Berkelanjutannya kampung Jambangan ini dipengaruhi oleh rasa sense of belonging masyarakatnya terhadap lingkungannya dan ini dimulai dari penguatan potensi kampung sehingga masyarakatnya sejahtera
\end{abstract}

Kata Kunci: Asian New Urbanism, Berkelanjutan, Kampung Kota 
Jurnal Planologi Vol. 17 No. 2, Oktober 2020

Available : http://jurnal.unissula.ac.id/index.php/psa

\section{PENDAHULUAN}

Kampung kota merupakan bagian dari permukiman yang ada di wilayah perkotaan dan memiliki ciri khas sebagai permukiman tidak terencana (unplanned). Timbulnya kampung kota dimulai dari tingginya angka urbanisasi di perkotaan. Hal ini tentunya menjadi sebuah respon spontan yang dilakukan oleh masyarakat perkotaan untuk memenuhi kebutuhannya dalam bermukim, sehingga seringkali ditemui status lahan yang dimiliki oleh masyarakat tidak jelas (Putera, 2014). Dampak dari keberadaannya yang terjadi secara spontan menyebabkan kampung kota memiliki karateristik yang tidak terstruktur, tidak terorganisir dan merupakan bagian dari permukiman informal dalam kaitannya dengan sistem sosial ekonomi (Letfiani \& Widyasari, 2015). Selain itu, sistem sosial penduduk yang tinggal di kampung kota masih membawa sifat dan prilaku kehidupan di pedesaan yaitu memiliki ikatan kekeluargaan yang erat sedangkan jika dilihat dari tingkat ekonominya yaitu kondisi fisik bangunan dan lingkungannya masih kurang baik (Heryati, 2011). Sehingga dari definisi tersebut dapat disimpulkan bahwa kemiskinan dan rendahnya kualitas lingkungan seperti sarana prasarana juga menjadi sebuah wajah kampung kota khususnya yang ada di Indonesia.

Permasalahan kampung kota yang ada di Indonesia tentunya masih belum dikatakan maksimal dalam menerapkan rencana aksi pembangunan berkelanjutan (SDGs). Ada empat point penting dalam SDGs (Sustainable Development Goals) guna mengurangi permasalahan kampung kota yaitu mewujudkan permukiman aman, berketahanan, inklusif dan berkelanjutan (tujuan ke-11). Warga kampung kota harusnya memiliki hak yang sama guna menikmati hidup yang layak, lingkungan hunian yang sehat dan terjangkau serta pemerataan terhadap pelayanan dan penyediaan infrastruktur dasar (Kustiwan \& Ramadhan, 2019). Untuk mewujudkan hal itu, tentunya membutuhkan peran masyarakatnya.

Kota Surabaya merupakan salah satu kota yang fokus dalam menggerakkan kampung-kampungnya ke arah berkelanjutan. Salah satu program yang sudah berjalan sejak tahun 2005 dan masih berlangsung sampai saat ini yaitu program Kampung Hijau atau dikenal dengan sebutan Surabaya Green and Clean. Kegiatan pada program ini tidak hanya dilakukan oleh pemerintah kota Surabaya tetapi juga mendapat dukungan dari berbagai pihak seperti Jawa Pos dan Unilever (Prasetiyo, 2019).

Saat ini Kampung Jambangan dikenal sebagai model kampung berkelanjutan di Kota Surabaya. Peran masyarakat Jambangan dalam mewujudkan sebagai kampung 
berkelanjutan di kota Surabaya salah satunya dalam bentuk partisipasi kemitraan/patnership (Mufidah \& Sari, 2017), dimana pemerintah dan masyarakat merupakan mitra yang sejajar. Masyarakat diberi kesempatan untuk mengeluarkan ide-ide ataupun solusi atas kondisi yang ada di masyarakat sesuai dengan kebutuhan.

Beberapa tulisan tentang Kampung Jambangan yang ada fokus pada empat hal yaitu (1) kampung belajar (2) kampung sehat (3) kampung asuh (4) kampung kreatif dan kampung aman ((Mufidah \& Sari, 2017); (Sugianti \& Ekomadyo, 2016); (Lecesnawati \& Prabawati, 2018)). Hal itu, menunjukan bahwa Kampung Jambangan telah menjadi kampung yang berkelanjutan. Tulisan ini fokus pada evaluasi kampung berkelanjutan Jambangan melalui pendekatan yang sesuai dengan prilaku/kebiasaan kehidupan di Asia yang dikenal sebagai pendekatan asian new urbanism (Grant, 2006).

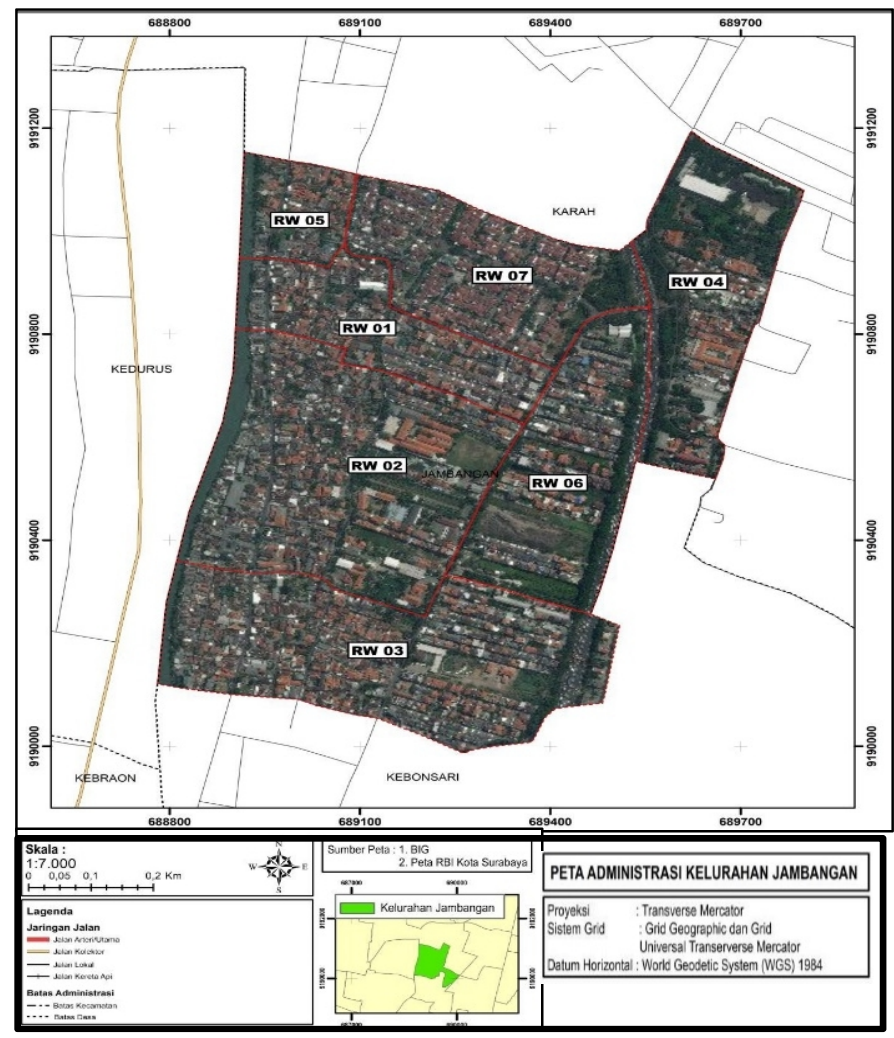

Gambar 1. PetaWilayah Studi Sumber: Kompilasi, 2020

\section{METODOLOGI}

Metode yang digunakan dalam penelitian ini adalah deskriptif dengan pendekatan kuatitatif. Metode deskripsi kuantitatif dilakukan untuk mengukur presentase hasil evaluasi kampung berkelanjutan di Jambangan. Guna menjaga keabsahan penelitian ini, maka menggunakan teknik keabsahan data melalui triangulasi. Jika dilihat dari definisinya 
triangulasi adalah teknik pemerikasaan keabsahan data dengan memanfaatkan sesuatu di luar data itu melalui pengecekan atau sebagai pembanding terhadap data tersebut (Oktavianti, 2018). Sehingga untuk penelitian ini menggunakan traingulasi peneliti. Triangulasi peneliti merupakan pemeriksaan hasil dari penelitian sendiri dengan beberapa penelitian lainnya guna menghasilkan keabsahan penelitian (Sugiyono, 2016). Variabel yang digunakan sesuai dengan indikator pendekatan asian new urbanism yaitu Self sufficiency; Shifting and floating values; Transport and mobility; Conservation of environmental; Land as resouce (tabel 1).

Tabel 1. Deskripsi Indikator Asian New Urbanism

\begin{tabular}{|l|l|}
\hline \multicolumn{1}{|c|}{ Indikator } & \multicolumn{1}{|c|}{ Deskripsi } \\
\hline Self sufficiency & $\begin{array}{l}\text { Point ini menjelaskan tentang pemenuhan kebutuhan kota yang } \\
\text { optimal dengan kondisi lahan kecil. Salah satunya adalah } \\
\text { pemanfaatan perkarangan rumah beruba urban farming }\end{array}$ \\
\hline Shifting and floating values & $\begin{array}{l}\text { Point ini menjelaskan nilai pemanfaatan lahan yang diletakkan } \\
\text { pada titik-titik pertumbuhan, sehingga pembangunan secara } \\
\text { vertikal dapat digunakan khususnya di Kawasan yang padat. }\end{array}$ \\
\hline Transport and mobility & $\begin{array}{l}\text { Fokus dari poin ini yaitu terkait keberadaan transportasi umum } \\
\text { dan prasarananya. }\end{array}$ \\
\hline $\begin{array}{l}\text { Conservation of } \\
\text { environmental }\end{array}$ & Fokus pada daerah yang dikonservasi \\
\hline Land as resouce & $\begin{array}{l}\text { Poin ini berkaitan dengan ketersediaan sumber daya lahan guna } \\
\text { mendukung kegiatan kampung berkelanjutan, seperti ruang untuk } \\
\text { kegiatan bersosial, ekonomi, dll }\end{array}$ \\
\hline
\end{tabular}

Sumber: ((Grant, 2006); (Makhmud et al., 2017))

\section{HASIL DAN PEMBAHASAN}

Berdasarkan hasil analisa data yang didapatkan bahwa 80 \% Kampung Jambangan telah menerapakan indikator asian new urbanism dalam mewujudkan kampung berkelanjutan. Secara terperinci dapat dijelaskan pada Tabel 2 tentang evaluasi kesesuaian kampung berkelanjutan Jambangan.

Tabel 2. Evaluasi Kesesuaian Kampung Berkelanjutan Jambangan melalui Pendekatan Asian New Urbanism

\begin{tabular}{|c|c|l|c|}
\hline No & $\begin{array}{c}\text { Indikator } \\
\text { Asian new } \\
\text { Urbanism }\end{array}$ & \multicolumn{1}{|c|}{ Kondisi Eksisting } & $\begin{array}{c}\text { Sesuai } \\
(\sqrt{ })\end{array}$ \\
\hline 1. & Self sufficiency & $\begin{array}{l}\text { Di Kampung Jambangan telah melakukan inovasi urban } \\
\text { farming di masing-masing rumah. Jenis tanaman seperti } \\
\text { sayur-sayuran hidroponik, tanaman toga, tanaman hias. }\end{array}$ & $\sqrt{ }$ \\
& $\begin{array}{l}\text { Inovasi yang dilakukan sebagai wadah tanaman tersebut } \\
\text { menggunakan botol-botol yang tidak digunakan kemudian } \\
\text { dipercantik dengan berbagai warna. Tidak hanya itu, hasil } \\
\text { dari tanaman toga kemudian dijadikan minuman herbal } \\
\text { (jamu) yang kemudian di jual. Hal ini selaras dengan } \\
\text { penelitian sebelumnya bahwa kampungan Jambangan sebagai }\end{array}$ & \\
\hline
\end{tabular}


Jurnal Planologi Vol. 17 No. 2, Oktober 2020

Available: http://jurnal.unissula.ac.id/index.php/psa

\begin{tabular}{|c|c|c|c|}
\hline No & $\begin{array}{l}\text { Indikator } \\
\text { Asian new } \\
\text { Urbanism }\end{array}$ & Kondisi Eksisting & $\begin{array}{c}\text { Sesuai } \\
(\sqrt{ })\end{array}$ \\
\hline & & $\begin{array}{l}\text { kampung sehat dan kampung kreatif (Sugianti \& Ekomadyo, } \\
\text { 2016) }\end{array}$ & \\
\hline 2. & $\begin{array}{l}\text { Shifting and } \\
\text { floating values }\end{array}$ & $\begin{array}{l}\text { Minimnya luas lahan di kawasan perkotaan, maka } \\
\text { pendekatan asian new urbanism yaitu dengan cara } \\
\text { pemanfaatan lahan mix use. Di kampung Jambangan guna } \\
\text { menjaga kelayakan hunian maka pembangunan dilakukan } \\
\text { secara vertical sehingga kebutuhan di lingkungannya } \\
\text { terpenuhi seperti toko (supermarket), apotek, warung } \\
\text { klontong, perbankan. Salah satu contohnya yaitu masyarakat } \\
\text { yang memiliki UMKM menggunakan lahannya menjadi dua } \\
\text { lantai yaitu lantai untuk tempatnya buka usaha kemudian } \\
\text { lantai ke dua yaitu tempat tinggal/hunian. Poin ini telah } \\
\text { sesuai dengan konsep kampung berkelanjutan yang } \\
\text { mengedepankan kreativitas melalui pemaduan antara } \\
\text { kegiatan ekonomi dan tempat hunian (Nassar \& Elsayed, } \\
\text { 2018) }\end{array}$ & $\sqrt{ }$ \\
\hline 3. & $\begin{array}{l}\text { Transport and } \\
\text { mobility }\end{array}$ & $\begin{array}{l}\text { Kampung Jambangan cukup strategis untuk mendapatkan } \\
\text { angkutan umum. Masyarakat dengan mudah bisa } \\
\text { mendapatkan angkutan umum. Jenis angkutan umum yang } \\
\text { melewati yaitu H2 dan H2P. Untuk yang jenis H2P melewati } \\
\text { Kelurahan Jambangan menuju arah Masjid Al Akbar } \\
\text { Surabaya sedangkan H2 melewati menuju ke area } \\
\text { Wonokromo. Namun keberlanjutan angkutan umum ini tidak } \\
\text { di dukung oleh prasarana angkutan publik seperti halte. }\end{array}$ & $\mathbf{X}$ \\
\hline 4. & $\begin{array}{l}\text { Conservation of } \\
\text { environmental }\end{array}$ & $\begin{array}{l}\text { Pada point ini lebih fokus terkait dengan lingkungan yang } \\
\text { wajib dikonservasi seperti daerah di sekitar sempadan sungai. } \\
\text { Saat ini keberadaan Kampung Jambangan juga mengalami } \\
\text { perubahan melalui pendekatan "membangun rumah, Madhep } \\
\text { Kali", yang artinya rumah-rumah di sekitar sungai telah } \\
\text { menghadap kali. Tujuan pendekatan ini menjadikan sungai } \\
\text { sebagai halaman depan dan mendorong penghuninya untuk } \\
\text { menjaga dan melestarikan sungai tersebut. Poin ini lebih } \\
\text { sesuai dengan konsep kampung sehat dan aman (Mufidah \& } \\
\text { Sari, 2017) }\end{array}$ & $\sqrt{ }$ \\
\hline 5. & $\begin{array}{l}\text { Land As } \\
\text { Resource }\end{array}$ & $\begin{array}{l}\text { Ketersediaan sumber daya lahan di kampung dapat } \\
\text { dimanfaatkan sebagai kegiatan masyarakat. Kampung } \\
\text { Jambangan saat ini telah memiliki gedung serba guna, ruang } \\
\text { untuk "bank sampah" serta taman-taman yang dimanfaatkan } \\
\text { untuk tanaman toga. Poin ini mencerminkan tentang } \\
\text { kampung belajar. }\end{array}$ & $\sqrt{ }$ \\
\hline
\end{tabular}

Sumber: Hasil analisis, 2020

Selain itu berdasarkan paparan hasil penelitian lainnya juga dikemukakan oleh beberapa pihak terkait dengan evaluasi kampung berkelanjutan. Menurut (Mintorogo, Arifin, Widigdo, \& Juniwati, 2005) menyebutkan bahwa kampung berkelanjutan harus bisa memperkenalkan berbagai aspek mulai dari aktivitas penghijauan (dimulai dari masing-masing rumah), mendaur ulang limbah kering dan limbah basah, pupuk ramah lingkungan, penanaman toga serta melakukan manajemen bank sampah. Aspek tersebut 
tentunya sudah dilakukan oleh Kampung Jambangan mulai dari pembuatan urban farming dengan jenis toga, membuat pupuk dari hasil limbah basah pada rumah tangga serta melakukan manejemen bank sampah.

Implementasi kampung berkelanjutan di Jambang memberikan tiga dampak terhadap masyarakat yaitu, pertama, tumbuhnya ekonomi kreatif melalui bank sampah yang ada di Kampung Jambangan dimana dilakukan dengan sistem menabung. Semakin banyak sampah yang dikumpulkan maka semakin banyak pula pendapatannya. Selain itu, hasil dari sisa sampah kering yang dikumpulkan oleh masyarakat dapat dijadikan kerajinan tangan seperti tempat pensil, tas, taplak meja. Disebutkan juga (Hamidah, Rijanta, Setiawan, \& Marfai, 2017) bahwa karateristik kampung berkelanjutan dengan cara menumbuhkan kreatifitas masyarakatnya melalui industri kerajinan dan industri daur ulang. Kedua, intensitas aktivitas ekonomi kreatif menumbuhkan rasa gotong royong sehingga peduli kepada lingkungan. Aktivitas ekonomi dan sosial ini tentunya membutuhkan suatu ruang untuk berkumpul sebagai penghuni kampung. Ketiga, terpeliharanya aktivitas ini akan menimbulkan sense of belonging terhadap lingkungan hunian tinggi (Kustiwan \& Ramadhan, 2019).

Selain tiga hal di atas mengenai evaluasi kampung berkelanjutan, peneliti menemukan temuan bahwa kampung berkelanjutan dapat dilakukan dengan baik ketika masyarakat sebagai penghuni kampung memiliki rasa sense of belonging kuat terhadap lingkungannya. Rasa sense of belonging yang tinggi dimulai dari penguatan potensi kampung melalui industri kreatif sehingga mewujudkan masyarakat yang sejahtera.

\section{KESIMPULAN DAN SARAN}

\subsection{Kesimpulan}

Kesimpulan yang bisa diambil dari penelitian ini yaitu evaluasi kampung berkelanjutan Jambangan yang sesuai dengan pendekatan asian new urbanism sebesar 80\%. Kampung berkelanjutan memberikan 3 dampak yaitu, ekonomi kreatif, sifat gotong royong pada masyarakat dan terpeliharanya lingkungan. Untuk mempertahankan kampung Jambangan sebagai salah satu kampung berkelanjutan maka masyarakat harus memiliki sense of belonging yang kuat yaitu dimulai dari penguatan potensi kampung dengan adanya industri kreatif. Industri kreatif ini dilakukan dengan berbagai macam cara seperti yang telah dilakukan Kampung Jambangan. Beberapa contohnya yaitu penanaman toga yang dapat dijakan produk jamu, manajemen bank sampah menghasilkan produk kerajinan. 
Jurnal Planologi Vol. 17 No. 2, Oktober 2020

Available : http://jurnal.unissula.ac.id/index.php/psa

\subsection{Saran}

Dilihat dari hasil kesimpulan penelitian, maka ditemukan adanya kekurangan khususnya pada sisi tranportasi dan mobilitas di kampung Jambangan. Belum adanya parkir dan tempat pemberhentian angkutan umum di Kampung Jambangan menyebabkan angkutan umum berhenti di tempat yang tidak sesuai dengan titiknya. Oleh karena itu dibutuhkan penelitian lanjutan terkait dengan rencana pengembangan transportasi guna mewujudkan kampung berkelanjutan.

\section{DAFTAR PUSTAKA}

Grant, J. (2006). Planning The Good Community: New Urbanism in Theory and Pratice. London: Routledge Published.

Hamidah, N., Rijanta, R., Setiawan, B., \& Marfai, M. A. (2017). Kampung sebagai Model Permukiman Berkelanjutan di Indonesia. Inersia - Jurnal Teknik Sipil Dan Arsitektur, 12(2), 114-124. https://doi.org/10.21831/inersia.v12i2.12586

Heryati. (2011). Kampung Kota sebagai bagian dari Permukiman Kota Studi Kasus : Tipologi Permukiman RW 01 RT 02 Kelurahan Limba B dan Rw 04 Rt 04 Kel. Biawu Kecamatan Kota Selatan Kota Gorontalo. Jurnal Universitas Negeri Gorontalo, 8(3), 11-13.

Kustiwan, I., \& Ramadhan, A. (2019). Strategi Peningkatan Kualitas Lingkungan Kampung-Kota dalam Rangka Pembangunan Kota yang Inklusif dan Berkelanjutan : Pembelajaran dari Kasus Kota Bandung. Journal of Regional and Rural Development Planning, 3(1), 64-84.

Lecesnawati, R., \& Prabawati, I. (2018). Implementasi Program Pengelolaan Sampah Dan Kebersihan Lingkungan Di RT 03 RW 03 Jambangan Kota Surabaya. Publika, 6(7), $1-6$.

Letfiani, E., \& Widyasari, A. (2015). Kampung Maspati As a Sustainable Kampung in Surabaya City. Journal of architecture \& Environment, 14(2), 163-172. https://doi.org/10.12962/j2355262x.v14i2.a2937

Makhmud, D. F., Nuhasanah, F., Utamai, I. U., Khansa, S., Radnawati, D., \& Syahadat, R. M. (2017). Mewujudkan Kampung Bandan Sebagai Kampung Kota Berkelanjutan Menggunakan Pendekatan Asian New Urbanism. Vitruvian Jurnal Arsitektur, Bangunan, \& Lingkungan, 6(3), 91-100. https://doi.org/10.1016/j.tmrv.2009.11.001

Mintorogo, D. S., Arifin, L. S., Widigdo, W. K., \& Juniwati, A. (2005). Historical Old “ Kampung " Toward Sustainable Green and Clean Habitat. (1992).

Mufidah, I., \& Sari, M. M. K. (2017). Partisipasi Masyarakat Jambangan Rw 03 Dalam Mewujudkan Surabaya Kota Layak Anak Melalui Progam Inisiasi Kampung ’ E Arek Suroboyo ( IKAS ) Immarotul Mufidah Maya Mustika Kartika Sari Kajian Moral dan Kewarganegaraan Kajian Moral Dan Kewarganegaraan, 5(2), 130-144.

Nassar, D. M., \& Elsayed, H. G. (2018). From Informal Settlements to sustainable communities. Alexandria Engineering Journal, 57(4), 2367-2376. https://doi.org/10.1016/j.aej.2017.09.004

Oktavianti, F. N. (2018). Analisis Tata Ruang Dalam Kenyamanan Kerja dan Optimalisasi Kinerja Bagian Humas dan Protokol Sekretariatan DPRD Kota Surakarta. Jurnal Informasi Dan Komunikasi Administrasi Perkantoran, 2(2), 71-84. 
Jurnal Planologi Vol. 17 No. 2, Oktober 2020 Available : http://jurnal.unissula.ac.id/index.php/psa

Prasetiyo, W. H., Kamarudin, K. R., \& Dewantara, J. A. (2019). Surabaya green and clean: Protecting urban environment through civic engagement community. Journal of Human Behavior in the Social Environment, 29(8), 997-1014.

Putera, Y. A. (2014). Ambiguitas Ruang Kampung Pluis Jakarta Selatan dalam Perspektif Privat-publik. E-Journal Graduate Unpar, 1(2), 101-110.

Sugianti, D. H., \& Ekomadyo, A. S. (2016). Strategi Kampung Kreatif sebagai Upaya Perbaikan Lingkungan Kota menurut Kerangka Pemenuhan Kebutuhan Manusia (Studi Kasus: Kampung Jambangan). Prosiding Temu Ilmiah IPLBI, 119-126.

Sugiyono, (2016). Metode Penelitian Kuantitatif, Kualitatif, dan R\&D. Bandung. Alfabeta 